\title{
Digital payments and consumer experience in India: a survey based empirical study
}

\author{
Sudiksha Shree ${ }^{1} \cdot$ Bhanu Pratap $^{2} \cdot$ Rajas Saroy $^{2} \cdot$ Sarat Dhal $^{2}$
}

Received: 16 October 2020 / Accepted: 12 November 2020 / Published online: 5 January 2021

(c) Institute for Development and Research in Banking Technology 2021

\begin{abstract}
Propelled by recent policy initiatives and technological developments, India's digital payment system is a promising success story in the making. At the same time, the data also points towards an increasing usage of cash. While aggregate country-level data can indicate overall preferences of citizens, we use a novel online survey-based dataset to understand how factors such as 'perception' and 'trust' in digital payments, and experience with online frauds, affect the payment behaviour of consumers. While demographic factors like age, gender and income are relevant factors which determine this choice, we find compelling evidence that a person's usage of digital payment methods is influenced by her perception of these instruments, as well as her trust in the overall payments framework and banking system in general. We find that the degree to which past-experience with online fraud deters usage of digital payments varies with the purpose of the transaction.
\end{abstract}

Keywords Cash usage $\cdot$ Payment systems $\cdot$ Digital payments $\cdot$ Logistic regression

JEL Classification E42 $\cdot$ C31

\section{Introduction}

The consensus around the origin and the forms of ancient money has kept changing over the course of recorded history. But, what has not changed over the years is what money does; broadly, it facilitates trade in goods and services as medium of exchange and acts as a credible store of value. Modern day trade demands massive payments to be settled

The views expressed are those of the authors and do not necessarily reflect the views of the Reserve Bank of India.

Sarat Dhal

scdhal@ rbi.org.in

Sudiksha Shree

sudi175@gmail.com

Bhanu Pratap

bhanupratap@rbi.org.in

Rajas Saroy

rajassaroy@rbi.org.in

1 Mumbai School of Economics and Public Policy, University of Mumbai, Mumbai, India

2 Department of Economic and Policy Research, Reserve Bank of India, Mumbai, India fast over long distances with minimum transaction cost. Evidently, to suit these needs the payment systems are being digitised globally. Cash, however, remains a crucial part of the trade. Therefore, the discourse on the current age payment system revolves around cash vs digital transactions.

While cash might seem convenient as it's ingrained in our habits and is still readily accepted at more places, digital payments offer convenience by saving time and labour. There are further issues with cash use. While it provides a suitablealternative to aid the informal or parallel economy $[3,21]$, digital payment offers itself as a desirable tool for institutions to fix this problem of traceability. In fact, governments around the world have taken drastic measures at huge costs to clear markets of 'black money'. Research in the behavioural sciences conveys that people experience higher 'pain of paying' when paying in cash than digitally, and this contributes to deferred payments $[17,19,20]$. While cash may not seem to impose any direct transactional cost like digital money, it is still costly for both governments and endusers. A 2014 study found out that residents of Delhi spent around 6 million hours and ₹91 million to access cash, while the Reserve Bank of India (RBI) and commercial banks together spent about ₹210 billion towards currency related operating expenses in the same year. But on the other hand, 
there are also huge implicit costs to digitise the existing systems and nudge people to change [14].

In the last decade, India has rapidly digitised its payment systems and promises huge potential in the area. Digital payments recorded an increase of $46.5 \%$ in total volume in FY19 on top of an increase of $60.6 \%$ in FY18. The Unified Payments Interface (UPI), a payment system that was launched in 2016, has surpassed the milestone of a billion transactions per month. The progress in digitisation has been driven by a healthy mix of technological innovation, policy interventions, and expansion and strengthening of existing infrastructure on the supply side, coupled with an increasing proportion of the population adopting financial and digital instruments on the demand side. The government of India and the RBI have been working in synergy to push for policy and regulatory reforms. Enablers such as Jan Dhan accounts, Aadhaar and penetration of mobiles, and policies like Demonetisation and Goods and Services Tax have brought people closer to technology and banks. Recently, NEFT (National Electronic Funds Transfer) was made operational for $24 \mathrm{~h}$ on all days of the week, and RTGS (Real Time Gross Settlement) is expected to follow soon. The launch of UPI, along with already available digital payment modes like NEFT, IMPS, cards and Prepaid Payment Instruments (PPIs) has increased the options available to the consumer. The number of PoS (point of sale) terminals have also increased by about 40 lakhs in the last five years. PoS terminals and lightweight acceptance infrastructure such as QR codes have boosted Card/PPI based payments. Additional payment systems such as Bharat Bill Payment System (BBPS), National Electronic Toll Collection (NETC) system, RuPay cards and AePS have also boosted digital payments and the intent to incorporate modern-day technologies such as tokenisation and contactless payments will further the progress.

Despite this progress, cash use still seems to be on the uptick in India. Our paper seeks to highlight the important factors at the individual level, which influence the consumer's decisions to use cash or digital payment. While it is critical to push for technological innovations and policy reforms, it is also imperative to understand the aspects that motivate or hinder the adoption of these technologies by the end-user. A recent survey [5], on the readiness of consumers towards adoption of newer payment technologies, ranked India second out of 27 economies on the FinTech adoption Index. Research conducted at the individual consumer level can provide an insight to understand how certain aspects are at play while making a payment decision. To this end, we use a comprehensive and multidimensional online survey which addresses many hitherto untouched dimensions of this topic, such as the difference in digital spending over various expenditure categories (groceries, e-commerce, utility bills, etc.), the choice of consumers to go purely digital or exercise a mix of cash and digital options, and the effect of psychological factors like perception and trust.

There is a dearth of studies and data covering the behavioural aspects at individual level that have an impact on choice of payment behaviour in the Indian economy. Given the massive heterogeneity of our population, different samples might produce disparate results. The High-Level Committee on Deepening Digital Payments [15] recommended that there should be periodic surveys to gauge user experience and attitude towards digital payments. The present study, is a small step towards filling the research gap in the context of such analysis.

Our key findings point towards a significant impact of perception of the payment system on how people choose to pay. Not only does a positive perception motivate people to go 'digital', but a relatively negative outlook on cash also has a similar impact. This finding is important in light of increasing cash use at the macroeconomic level in the country. Another significant factor is confidence in the payment system. Respondents who trust the service providers and regulators seem to have a greater likelihood of paying digitally. We find inconsistent behaviour when studying the impact of experience of digital payment fraud on choice of payment tool. The impact that experiencing such a fraud has on the choice to pay digitally differs according to the purpose of the transaction. The remainder of the study is presented in five sections pertaining to existing literature, data and methodology, sample summary statistics, empirical findings and conclusion and policy implications.

\section{Related literature}

The terms digital transaction, electronic transactions, paperless transaction or cashless transaction are almost used interchangeably in common parlance. The RBI Ombudsman Scheme for Digital Transactions (2019) defines digital transactions as "a payment transaction in a seamless system effected without the need for cash at least in one of the two legs, if not in both. This includes transactions made through digital/electronic modes wherein both the originator and the beneficiary use digital/electronic medium to send or receive money". However, in our paper, a digital transaction is one where the payer and payee both use digital modes of payment.

Policies in many parts of the world are being designed in favour of non-cash payments because of the various problems that cash poses. Cash fuels the parallel or black economy, therefore, phasing it out might solve this problem, especially with large denomination notes [20]. The cost of printing, destroying and other cash related operational expenses in India are estimated at 1.7\% of GDP [23]. Cash, however, remains a significant part of all the transactions in most countries [6]. 
While reading into data on the macro-level can give us a broad idea of people's overall preferences, data at the individual level gives us an insight into how certain factors impact the choices/decisions consumers make regarding the mode of payment. Following this line of thought, several studies have analysed such issues at the level of the consumers. They reveal that the choice of payment method is impacted by a host of consumer-specific and technological factors. Transaction size has a significant impact on what mode of payment people choose. A cross- country comparison of payment diary survey data of seven countries showed that cash was the preferred mode of payment for smallest $50 \%$ and largest $25 \%$ of transactions [2]. In another study, social marginal costs were computed for various instruments for small and large transaction sizes and it was found that for larger transaction sizes, there were significant differences in cost for electronic vs non-electronic payments [8]. Studies show that demographic characteristics also play a significant role in how people choose to pay. It was found that better education and higher income lead to lower cash use compared to non-cash modes. Certain categories of age show a stronger preference for digital payments Bagnall et al. [2].

Consumer perceptions on safety/risk, convenience/ease of use, anonymity and costs have been shown to affect payment systems adoption significantly. Png and Tan [16] show that concerns about privacy emerged as one of the main psychological factors causing a bias towards cash for retail transactions. Kahn et al. [10] show that business in the unorganised economy was attributed to transactions that could be made in cash and did not reveal the agent's identity. Bagnall et al. [2] analysed data from cross-country consumer diary surveys and found that consumers who rated cash high on 'ease of use' ended up using it more. In a study assessing payment perception of Dutch consumers, non-price parameters such as 'acceptance', 'convenience', 'transaction speed' and 'safety' were used to gauge the perception of payment instruments used at PoS terminals [9]. Several studies have used the Technology Acceptance Model (TAM) to show 'perceived usefulness' and 'perceived ease of use' have a significant impact on behavioural intention and thus, actual use of electronic payment systems $[12,18]$.

Perceived trust in the payment system is shown to have a positive effect on the usage of digital modes of payment [13]. While the central bank and banks are traditional regulators and service providers of payments systems respectively, non-banks have also emerged as new players in the framework. A recent empirical study conducted by the Monetary Authority of Singapore [16] found that trust in banks impacts the nature of the transaction. A crosscountry analysis shows that residents in countries that reported lower trust in banks preferred cash for making transactions. In some cases, while an increase in trust can lead to the opening of accounts, it might not translate to actual usage of those accounts [7]. Central banks also play a pivotal role in ensuring safety, integrity and stability of the payments system. Experience of online fraud can shape beliefs of perception and trust and can have a direct impact on payment behaviour. Media coverage of these incidents is shown to affect card payment [11]. The direction, strength and frequency of media coverage affected debit card use. Few studies show that people simply use digital modes of payment because they have exhausted their stock of cash in hand. It is called 'cash first' or 'cash-burning' and is perceived to be an optimal policy by the consumer [1]. Some studies also point that people still pay in cash simply because it is difficult to grow out of habits [9].

\section{Survey data and empirical methodology}

For the purpose of this study, primary data is collected using a structured questionnaire circulated online (Appendix 1). Following snowball sampling, the survey was shared on various social media platforms for better reach. The questionnaire was drafted in English and Hindi, to both expand and diversify the sample. It consists of 28 questions that are divided into seven sections viz. demographics, access to and usage of technology, awareness of different modes of digital payment, preference and perception on cash and digital payment systems, spending habits, experience related to fraud, and feedback on awareness campaigns.

Our study broadly aims to understand the impact of user perception, trust in payment systems, and experience of online fraud on the choice of mode of payment. For regression analysis, mode of payment is taken as the dependent variable and the independent variable is added to a baseline model according to the hypothesis being tested. Firstly, a baseline model is obtained for all five types of purchasesgrocery, utilities, online shopping, durables, and gold. These transactions range from low to high value transactions. The responses recorded for different types of purchases have the following three alternatives:

- Always pay in cash,

- Always pay digitally, and

- Sometimes pay in cash and sometimes digitally.

Since the dependent variable is categorical and has more than two categories, a multinomial logistic regression is best suited for regression analysis. A multinomial logit model is an extension of logit model, with more than two categories, in no particular order. Maximum likelihood estimation is used to obtain the parameters of the model.

Let the model have $j=1,2 \ldots, J$ categories for the dependent variable $y$, and $X$ be the matrix of independent variables. In a multinomial logit model, we estimate a set of 
coefficients $\beta_{j}=\left(\beta_{1,} \beta_{2 \ldots}, \beta_{J}\right)$ corresponding to each outcome $j$. Setting $j=1$ as the reference or base category (i.e., $\beta_{1}=0$ ), we have:

$\operatorname{Pr}(y=1 \mid X)=\frac{1}{1+\sum_{j=2}^{J} \exp \left(x_{i} \beta_{j}\right)} \quad$ for $\mathrm{j}=1$

$\ln \left[\frac{\operatorname{Pr}(y=1 \mid X)}{\operatorname{Pr}(y=0 \mid X)}\right]=\beta_{01}+\beta_{11}$ gender $_{i}+\beta_{21}$ age $_{i}+\beta_{31}$ education $_{i}$

$+\beta_{41}$ income $_{i}+\beta_{51}$ occupation $_{i}+\beta_{61}$ placeofresidence $_{i}$

$\ln \left[\frac{\operatorname{Pr}(y=2 \mid X)}{\operatorname{Pr}(y=0 \mid X)}\right]=\beta_{02}+\beta_{12}$ gender $_{i}+\beta_{22}$ age $_{i}+\beta_{32}$ education $_{i}$

$+\beta_{42}$ income $_{i}+\beta_{52}$ occupation $_{i}+\beta_{62}$ placeofresidence $_{i}$
$\operatorname{Pr}(y=j \mid X)=\frac{\exp \left(X \beta_{j}\right)}{1+\sum_{j=2}^{J} \exp \left(x_{i} \beta_{j}\right)} \quad$ for $\mathrm{j}>1$

The parameters of the model are reported in terms of odds or log odds. Given any two possible categories for the dependent variable:

$\frac{\operatorname{Pr}(y=m \mid X)}{\operatorname{Pr}(y=n \mid X)}=\exp \left(X\left(\beta_{m}-\beta_{n}\right)\right)$

$\ln \left[\frac{\operatorname{Pr}(y=m \mid X)}{\operatorname{Pr}(y=n \mid X)}\right]=\Omega_{m: n}(X)=X\left(\beta_{m}-\beta_{n}\right)$

where $\left(\beta_{m}-\beta_{n}\right)$ is the effect of $X$ on log of odds of $m$ versus $n$. To get parameters of other categories of the outcome, they are similarly compared to the common reference category. For our study, cash usage is taken as the reference category. We begin by creating a baseline logistic regression model by taking demographic characteristics such as gender, age, education, family income, occupation, and place of residence as categorical independent variables. The dependent variable is coded as:

- $y=0$ for cash (reference)

- $y=1$ for digital payments

- $y=2$ for sometimes cash and sometimes digital payments

The following multinomial logistic model is estimated:

The parameter $\beta_{k j}$ is a vector of $\beta_{0 j}, \beta_{1 j} \ldots \beta_{k j}$ where $j$ $(j=0,1,2)$ is the category of dependent variable and there are $K+l(k=0,1, \ldots, K)$ independent variables. Since cash is the reference category, $\beta_{k 0}$ is set to 0 . Therefore, $\beta_{k l}$ and $\beta_{k 2}$ are respective log odds relative to the reference category.

Since, all the independent variables are categorical, they are coded as dummy variables. The reference categories for each of the independent variable in the baseline model are mentioned in the first column of Table 1 below.

Next, we add four additional independent variables of interest to the baseline model one by one, to observe the impact of perception (of both cash and digital payment modes separately), confidence in the payment system and fraud experience on the choice to pay digitally.

The perception of cash and digital modes of payment is recorded for four parameters- cost, convenience, safety and privacy/anonymity on a three-point Likert scale with the alternatives 'bad' (0), 'okay' (1) and 'good' (2). The mean score for perception is computed as the simple average of parameter-wise scores for cash and digital payments. Confidence in payment systems is measured on the

Table 1 Demographic variables

\begin{tabular}{llllll}
\hline Variables & Category-1 (baseline) & Category-2 & Category-3 & Category-4 & Category-5 \\
\hline Gender & Female & Male & Transgender & & \\
Age & $\leq 25$ & $26-45$ & $>45$ & & \\
Education & Completed 12th standard & Bachelor's degree & Master's degree & & \\
Family income & $<2.5$ lakhs & $2,50,000-5,00,000$ & $5,00,001-10,00,000$ & $10,00,001-25,00,000$ & $>25$ lakhs \\
Occupation & Salaried & Self-employed & Retired & Student & Others \\
Place of residence & Tier-3 $(\mathrm{z})$ & Tier-1 $(\mathrm{x})$ & Tier-2 $(\mathrm{y})$ & & \\
\hline
\end{tabular}


parameters- trust in the RBI, trust in your payment service providers (e.g. FinTechs) and trust in stability and integrity of your bank. A five-point Likert scale is to measure responses, ranging from strongly agree (0) to strongly disagree (4). The mean score is computed as a simple average of the four parameters. Online fraud experience is quantified based on familiarity with such incidents. The respondents were asked to choose from following alternatives-
- I have been a victim to digital payment frauds.

- I have received such calls/mails/texts but carefully avoided them.

- I have not received such calls/mail/texts but know someone personally who has been a victim.

- I have not received such calls/mail/texts and do not know anyone personally who has been a victim.

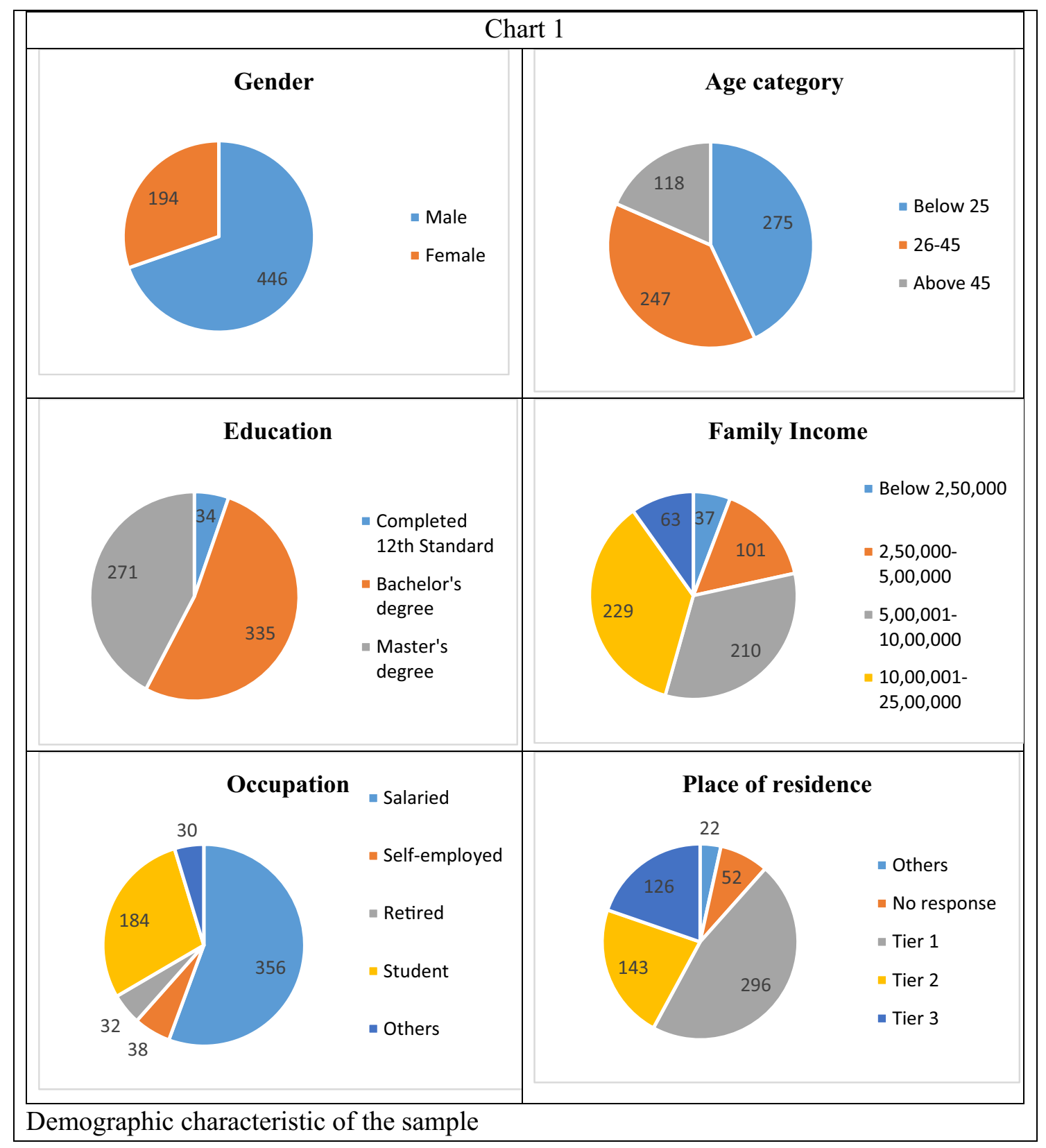

Chart 1 Demographic characteristic of the sample 


\section{Sample summary statistics}

A snapshot of our sample of 640 respondents is given in Chart 1 . The respondents are mostly male and educated. Most of them are either salaried employees, working in the government or private sector. This may be due to the online nature of the survey, and circulation limited to the social circles of the authors, which occurred due to the enforcement of the COVID-19 induced nationwide lockdown in India during the survey period. Responses were received from twenty states of India. The corresponding districts were divided into three tiers according to the HRA (Housing Rent Allowance) classification by the Department of Expenditure, Government of India.

The responses are summarised in Appendix 2. Awareness as well as usage regarding various digital payment instruments were high in the sample. It is important to keep this in mind while interpreting how payment behaviour is affected by other variables. Our respondents, being from the relatively well-off sections of society, were much more aware and comfortable with cards and UPI, rather than AEPS and USSD code-based payments. Digital mode was preferred for online shopping, paying utility bills, and purchasing durables (mostly medium to high value transactions). A combination of cash and digital modes was preferred for purchases of grocery and gold, which are starkly different in terms of transaction value. Being solely dependent on cash was relatively less preferable for all purposes.

The perception of cash and digital payments are recorded on four parameters viz., 'convenience', 'cost of payment', 'safety', and 'privacy/anonymity'. It is observed that on an average, digital payments perform better than cash on all four fronts. Confidence in digital payment systems is assessed on four parameters, with regards to banks (preference for depositing money in a bank, as well as trust in one's own bank), the central bank and in other participants like payment aggregators. Respondents seemed more confident in the RBI and banks, as compared to other service providers.

Technical issues, followed by low acceptance and lack of trust were identified as the major hindrances with digital payments. The experience of online fraud is divided into four categories based on their potential intensity of impact of the fraud. Out of 630 respondents that answered the question, 532 have had some experience of online fraud. Out of 411 respondents who had experienced the incident personally, a majority (279) reported no change in the nature of payments and only 26 mentioned that either they had completely switched to cash or had reduced the use of digital mode of transaction. Respondents were also asked if they reported the incident to the concerned authority after they experienced the fraud personally. Most of the respondents did not report the incident, especially if they had not faced any losses.

\section{Multinomial regression model: results and analysis}

The baseline model (Appendix 3) provides insights on the effect of demographics on the choice of mode of payment.

\subsection{Effect of demographics on mode of payment}

Males are more likely to use digital modes of transaction as compared to their female counterparts for both purely digital or a combination of cash and digital instruments. With respect to age, there is pressing evidence in the case of online shopping that older individuals are less likely to pay digitally. While the coefficients are not statistically significant for other kinds of purchases, their signs support this general observation. Education is also seen to have an enabling effect on people when it comes to going digital. The tendency to avoid paying solely with cash for groceries and utilities dwindles with an increase in the level of education of the respondent. Income levels have a statistically significant, positive impact when it comes to online shopping and gold purchases through the exclusively digital payment route. Lower income groups may prefer paying using cash on delivery. Occupation and place of residence have a significant impact on choice of mode of payment for mid and high-value transactions. Homemakers, unemployed and self-employed respondents are least likely to pay digitally. For place of residence, respondents living in Tier-1 cities are more likely to pay digitally.

In general, our results point out that more affluent and privileged groups are still more likely to go digital, compared to disadvantaged groups. Hence, while efforts to expand relevant infrastructure and nudge behavioural change are welcome, an upliftment of the general standard of living of the public, education and urbanisation may also be important ways to promote digitisation of payments.

\subsection{Experience of online fraud}

The experience of digital payment fraud is measured on a scale of four, with ' 0 ' implying 'I have been a victim of digital payment fraud, which is the highest possible impact of fraud on a person. At the other end, ' 3 ' stands for 'neither experienced digital payments fraud nor know anyone who has been a victim'. The baseline model is augmented with these additional categorical variables, and the results are presented in Table 2. The reference category for the four fraud indicator variables is the response ' 3 ', i.e., the respondent has neither been a victim of digital payment 
Table 2 Experience of Online fraud

\begin{tabular}{|c|c|c|c|c|c|}
\hline \multicolumn{6}{|l|}{ Reference category: Cash } \\
\hline & Grocery & Utilities & Durables & Online shopping & Gold \\
\hline I have been a victim (Cash) & 0 & 0 & 0 & 0 & 0 \\
\hline I have been a victim (DP) & $-1.416 * *(0.720)$ & $1.781(1.094)$ & $0.515(0.873)$ & $-0.515(0.822)$ & $-0.337(0.563)$ \\
\hline I have been a victim (Both DP and Cash) & $-0.578(0.501)$ & $1.927 *(1.114)$ & $1.454 *(0.837)$ & $0.086(0.791)$ & $-0.243(0.508)$ \\
\hline Have experienced but avoided (Cash) & 0 & 0 & 0 & 0 & 0 \\
\hline Have experienced but avoided (DP) & $-0.588(0.479)$ & $0.167(0.418)$ & $0.475(0.440)$ & $0.225(0.553)$ & $0.557(0.398)$ \\
\hline Have experienced but avoided (Both Cash and DP) & $-0.336(0.353)$ & $0.088(0.452)$ & $0.185(0.434)$ & $-0.166(0.541)$ & $0.254(0.370)$ \\
\hline Have not experienced but know (Cash) & 0 & 0 & 0 & 0 & 0 \\
\hline Have not experienced but know (DP) & $-1.062 *(0.546)$ & $-0.216(0.470)$ & $0.515(0.514)$ & $0.601(0.656)$ & $0.444(0.469)$ \\
\hline Have not experienced but know (Both Cash and DP) & $-0.922 * *(0.390)$ & $0.012(0.505)$ & $0.281(0.511)$ & $0.040(0.645)$ & $0.446(0.430)$ \\
\hline Do not know anyone & 0 & 0 & 0 & 0 & 0 \\
\hline Observations & 547 & 543 & 511 & 542 & 459 \\
\hline $\mathrm{R} 2$ & 0.153 & 0.109 & 0.139 & 0.142 & 0.087 \\
\hline Log Likelihood & -447.944 & -435.269 & -411.958 & -415.276 & -444.381 \\
\hline LR Test $(\mathrm{df}=38)$ & $162.420 * * *$ & $106.162^{* * *}$ & $132.754 * * *$ & $137.598 * * *$ & $84.907 * * *$ \\
\hline
\end{tabular}

${ }^{*} p<0.1 ; * * p<0.05 ; * * * p<0.01$

fraud, nor do they know of someone who has. Our paper highlights that frauds have differential impact based on the purpose of the transaction. For grocery payments, experiencing such frauds, first hand or otherwise, seems to demotivate people from using digital payment modes, but there is no such evidence for other types of transactions. In fact, respondents preferred using a mix of digital payments and cash for utilities and durables even if they had previously fallen prey to such frauds. It may be easier for consumers to switch to cash for grocery purchase, as compared to settling utility bills or buying durables.

\subsection{Perception of cash vs digital payments}

Perception of cash is scored on four parameters- cost of payment through cash, convenience of payment, privacy or anonymity concerns about the payment, and safety of payment. The scores range from 0 (bad) to 2 (good). The total score is computed by taking an average of all the four parameters. The total score is a continuous variable and is added to the baseline model. The resultant coefficient is reported in log odds. As is evident from Table 3, perception of cash has a strong and significant impact on which mode of payment is chosen by the respondent. As the perception of cash improves, the likelihood of paying digitally decreases across all purchase categories. The reference alternative for payment is taken as payments made only/ always in cash, implying no (zero) relation with perception of cash. As perception improves the likelihood decreases most for grocery (low-value payment) and online payments and least for payments made for purchasing gold followed by durables, both high-value payments.

Table 3 Perception of cash

\begin{tabular}{llllll}
\hline Reference alternative (Cash) & & & & \\
\hline & Grocery & Utilities & Durables & Online shopping & Gold \\
\hline Perception of cash (Cash) & 0 & 0 & 0 & 0 & 0 \\
Perception of cash (DP) & $-1.663^{* * *}(0.364)$ & $-1.141^{* * *}(0.341)$ & $-1.359^{* * *}(0.397)$ & $-2.150^{* * *}(0.465)$ & $-0.907 * * *(0.314)$ \\
Perception of cash (Both & $-0.926^{* * *}(0.285)$ & $-0.356(0.359)$ & $-0.762^{*}(0.390)$ & $-1.281^{* * *}(0.456)$ & $-0.546^{*}(0.300)$ \\
$\quad$ cash and DP) & 525 & 522 & & 520 & 451 \\
Observations & 0.168 & 0.123 & 497 & 0.167 & 0.090 \\
R2 & -422.114 & -408.150 & -399.130 & -384.794 & -435.351 \\
Log Likelihood & $170.334 * * *$ & $114.290^{* * *}$ & $130.397 * * *$ & $154.060^{* * *}$ & $85.768 * * *$ \\
\hline LR Test (df=34) & & &
\end{tabular}

$D P$ digital payments

${ }^{*} p<0.1 ; * * p<0.05 ; * * * p<0.01$ 
Table 4 Perception of digital payments

\begin{tabular}{llllll}
\hline Reference alternative (Cash) & & & & \\
\hline & Grocery & Utilities & Durables & Online shopping & Gold \\
\hline Perception of DP (Cash) & 0 & 0 & 0 & 0 & 0 \\
Perception of DP (DP) & $2.609^{* * *}(0.437)$ & $1.321^{* * *}(0.370)$ & $1.099^{* *}(0.429)$ & $1.665^{* * *}(0.494)$ & $0.757^{* *}(0.342)$ \\
Perception of DP (Both cash & $1.167^{* * *}(0.315)$ & $0.729 *(0.400)$ & $0.737 *(0.433)$ & $1.159^{* *}(0.497)$ & $0.307(0.331)$ \\
$\quad$ and DP) & & 532 & & 526 & 454 \\
Observations & 0.186 & 0.115 & 0.129 & 0.142 & 0.085 \\
R2 & -418.490 & -416.908 & -405.154 & -400.593 & -440.790 \\
Log Likelihood & $191.235^{* * *}$ & $108.487 * * *$ & $120.389^{* * *}$ & $132.798^{* * *}$ & $81.532^{* * *}$ \\
LR Test (df=34) & &
\end{tabular}

On the flip side, we also consider the total score for perception of digital payments, which is calculated similar to that for cash above. The coefficients (Table 4) are positive and statistically significant, implying that as perception improves, so does the likelihood of paying digitally. Here also, the reference alternative is using only cash. In terms of magnitude, the perception variables seem to affect grocery spends the most and gold spends the least. It can be inferred that a positive outlook on digital payment modes motivates the respondent to pay digitally. However, digital payments still have a long way to go if they are to prove themselves as good substitutes to the cheapness, convenience and privacy of cash use. Another observation from the above results is that high-value payments (gold and durables) are relatively less affected by perception of modes of payment, when compared to low- value payments (grocery).

\subsection{Trust in payment system}

Besides their perception of payment modes, respondents were also asked about their trust or confidence in the payment system as a whole, which was measured on four parameters. A five-point Likert scale is used, with '0' or 'strongly agree' implying high confidence in the payment system and
'4', which stands for 'strongly disagree' implying extreme lack of confidence in the payment system. The total score is computed by taking an average of scores obtained on all the parameters. As expected, a deterioration in consumer confidence in digital payment systems (or an increase in the 'lack of trust' score) worsens the likelihood of paying digitally (Table 5).

At the end of the survey, respondents were also asked to give their feedback on digital payments. This gives us an indication of overall sentiments and main concerns of consumers towards digital payments. In Chart 2, a 'wordcloud' based on 50 most frequently occurring words in the feedback highlights that consumers favour the 'convenience' offered by digital payment methods and have an overall positive sentiment towards such technology-based inventions.

\section{Conclusion}

While governments, regulators and service-providers are working in synergy to enhance the electronic payments systems and related infrastructure, it makes sense to study how these options are perceived by the end-user. The key policy recommendation from our study is that incorporating

Table 5 Trust in the payment system

\begin{tabular}{|c|c|c|c|c|c|}
\hline \multicolumn{6}{|c|}{ Reference alternative $=$ cash } \\
\hline & Grocery & Utilities & Durables & Online shopping & Gold \\
\hline Lack of trust (Cash) & 0 & 0 & 0 & 0 & 0 \\
\hline Lack of trust (DP) & $-1.104 * * *(0.279)$ & $-0.568 * *(0.240)$ & $-1.182 * * *(0.262)$ & $-1.101 * * *(0.294)$ & $-0.741 * * *(0.225)$ \\
\hline $\begin{array}{l}\text { Lack of trust (Both } \\
\text { Cash and DP) }\end{array}$ & $-0.462 * *(0.191)$ & $-0.165(0.255)$ & $-0.434 *(0.246)$ & $-0.593 * *(0.286)$ & $-0.424 * *(0.207)$ \\
\hline Observations & 531 & 529 & 501 & 527 & 448 \\
\hline R2 & 0.156 & 0.107 & 0.157 & 0.160 & 0.094 \\
\hline Log Likelihood & -433.684 & -425.970 & -396.993 & -397.368 & -431.058 \\
\hline LR Test $(\mathrm{df}=34)$ & $159.771 * * *$ & $102.351 * * *$ & $147.846^{* * *}$ & $150.876^{* * *}$ & $89.540 * * *$ \\
\hline
\end{tabular}

$* p<0.1 ; * * p<0.05 ; * * * p<0.01$ 
Chart 2 Textual analysis on feedback

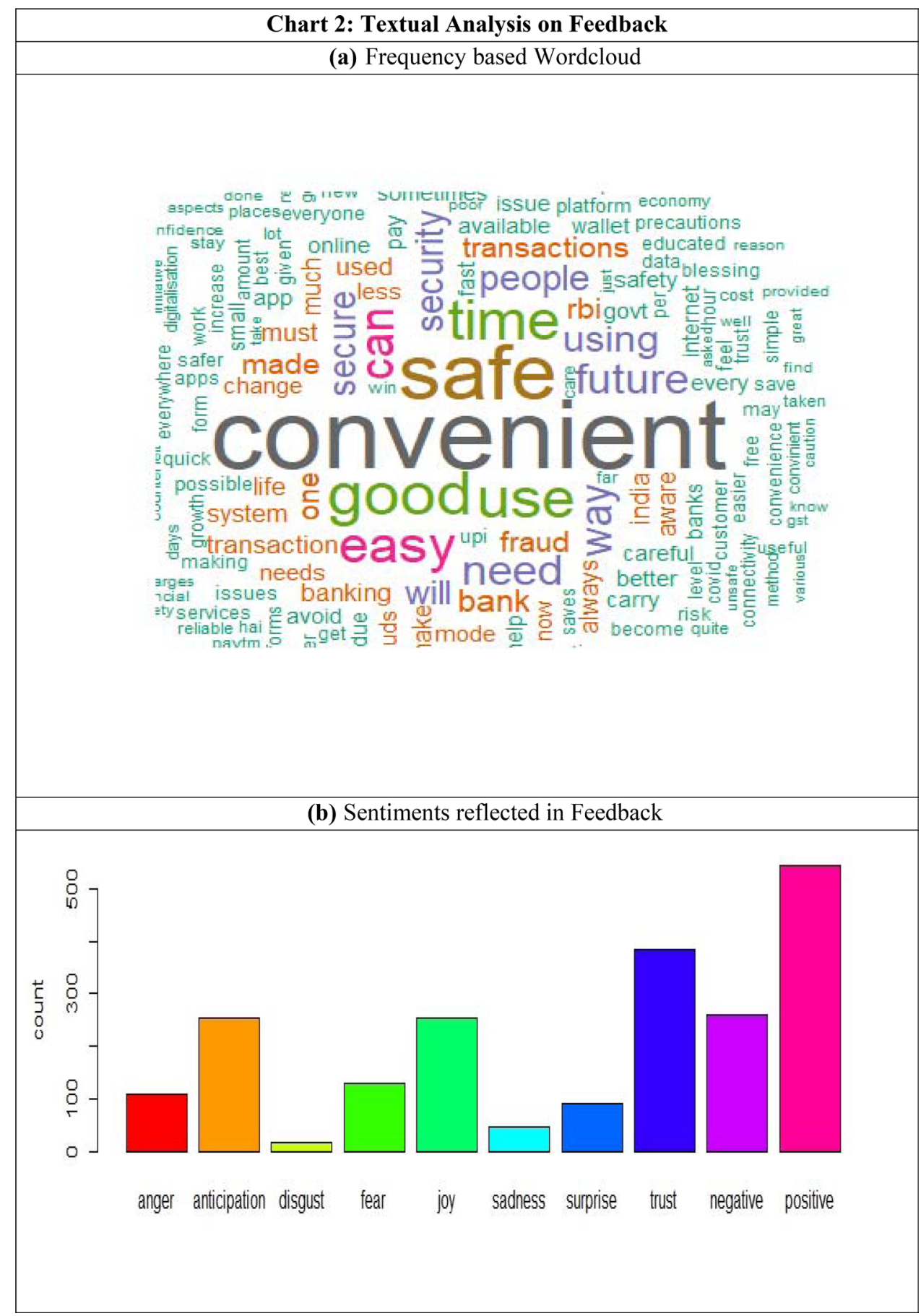

feedback and gauging public perception can further catalyse digitisation. We observe through our study that perception of digital payment instruments affects the payment behaviour of an individual. Digital payments were not only driven by a positive outlook on digital payments but also a negative outlook on cash. Contrary to popular belief, customers were seen to be willing to discount online fraud experience in the face of higher convenience offered by digital payment modes. The impact of experiencing fraud on the choice to pay digitally differs according to the purpose of the transaction. Also, we cannot ignore the role played by demographic factors in better digital payment adoption. Digital payments adoption is expected to increase in line with the overall socioeconomic development of the population.

While our collected data is from a geographically diverse set of respondents, it is still limited to a certain part of the population. The data has been collected during a countrywide lockdown and therefore could only include respondents 
who were willing to fill the survey online (English or Hindi). Thus, most of the respondents were already digitally literate, educated and economically sound when compared to the population. This is one of the major limitations of the study. Further, since responses were collected in extraordinary circumstances of nationwide lockdown, they may be biased in the sense that these were times when many were compelled to pay digitally for fear of contracting COVID-19. Also, e-commerce and technology firms (with higher acceptance of digital payments) had stepped up their services, filling in the vacuum created by closure of brick and mortar stores. Various central banks around the world conduct payment diary surveys to gauge useful variables at the individual level and observe their impact on payment behaviour. In the future, surveys like these could be taken up with a broader sample and in a more structured manner, as things gradually return to normal.

\section{Appendix 1}

\section{Survey on consumer experience and perception about digital modes of payments: questionnaire}

See Appendix Tables 6, 7, 8, 9, 10, 11, 12.

Table 6 A. Demographics

\begin{tabular}{|c|c|c|}
\hline Question number & Question & Coded option \\
\hline A_1(S1) & Gender & $\begin{array}{l}\text { 0. Female } \\
\text { 1. Male } \\
\text { 2. Other }\end{array}$ \\
\hline $\begin{array}{l}\text { A_2 } \\
(\mathrm{S} 2)\end{array}$ & Age & $\begin{array}{l}\text { 0. Below } 18 \\
\text { 1. } 18-25 \\
\text { 2. } 26-45 \\
\text { 3. } 46-60 \\
\text { 4. Above } 60\end{array}$ \\
\hline $\begin{array}{l}\text { A_3 } \\
\text { (S3) }\end{array}$ & Education & $\begin{array}{l}\text { 0. Never attended school } \\
\text { 1. Completed 5th standard } \\
\text { 2. Completed 10th standard } \\
\text { 3. Completed 12th standard } \\
\text { 4. Bachelor's degree } \\
\text { 5. Master's/M.Phil/PhD }\end{array}$ \\
\hline $\begin{array}{l}\text { A_4 } \\
(\mathrm{S} 4)\end{array}$ & FAMILY income (Yearly, Rupees) & $\begin{array}{l}\text { 0. Below } 2,50,000 \\
\text { 1. } 2,50,000-5,00,000 \\
\text { 2. } 5,00,001-10,00,000 \\
\text { 3. } 10,00,001-25,00,000 \\
\text { 4. } 25,00,001-50,00,000 \\
\text { 5. Above } 50,00,000\end{array}$ \\
\hline $\begin{array}{l}\text { A_5 } \\
\text { (S5) }\end{array}$ & Occupation & $\begin{array}{l}\text { 0. Salaried Employee (Private sector) } \\
\text { 1. Salaried Employee (Government or Public sector) } \\
\text { 2. Self-employed/Business owner } \\
\text { 3. Daily worker/Daily wage earner } \\
\text { 4. Retired person } \\
\text { 5. Student } \\
\text { 6. Home maker } \\
\text { 7. Unemployed (looking for a job) }\end{array}$ \\
\hline $\begin{array}{l}\text { A_6 } \\
\text { (S6) }\end{array}$ & $\begin{array}{l}\text { Place of residence (district, for maximum part of the } \\
\text { last } 12 \text { months) }\end{array}$ & $\begin{array}{l}\text { 1. Metropolitan: } 10 \text { lakh and above } \\
\text { 2. Urban: } 1 \text { lakh and above and less than } 10 \text { lakh } \\
\text { 3. Semi-Urban: } 10,000 \text { and above and less than } 1 \\
\text { lakh } \\
\text { 4. Rural: population less than } 10,000 \\
\text { A_6_2 } \\
\text { House Rent Allowance (HRA) classification by } \\
\text { Ministry of Expenditure } \\
x \text { list of cities } \\
\text { y list of cities } \\
\mathrm{z} \text { list of cities/towns that do not fall under } \mathrm{x} \text { or } \mathrm{y} \\
\text { (According to Census, 2011) }\end{array}$ \\
\hline
\end{tabular}


Table 7 B. Access to and usage of technology (mobile phone, computer and internet)

\begin{tabular}{llll}
\hline Question number & Question & Sub-question & Options \\
\hline B_1 & Please tick the checkboxes that best & B_1_1_1 (Access) and B_1_1_2 & 0. I have access to/not comfortable using \\
apply to you. (Please note: You can & (Comfort) & 1. I have access to/comfortable using \\
& be comfortable using what you do not & Basic phone & \\
have access to) & B_1_2_1 (Access) and B_1_2_2 & \\
& (Comfort) & \\
& Smartphone & \\
& B_1_3_1 (Access) and B_1_3_2 & (Comfort) \\
& Computer/Laptop \\
& B_1_4_1 (Access) \\
& Internet connectivity \\
& (BAD quality) \\
& B_1_5_1 (Access) \\
& Internet connectivity \\
& (GOOD quality) \\
&
\end{tabular}

Table 8 C. Awareness on different modes of digital payments, risks related and savings/investment instruments

\begin{tabular}{|c|c|c|c|}
\hline Question number & Question & Sub-question & Options \\
\hline $\begin{array}{l}\text { C_1 } \\
(\mathrm{S} 7)\end{array}$ & $\begin{array}{l}\text { Which of these Digital payments are you } \\
\text { AWARE of? }\end{array}$ & $\begin{array}{l}\text { C_1_1 } \\
\text { Credit/debit cards } \\
\text { C__1_2 } \\
\text { Point of Sale (Usually a handheld device to } \\
\text { insert card at point of sale) } \\
\text { C_1_3 } \\
\text { UPI (Unified payments interface) } \\
\text { C_1_4 } \\
\text { Internet banking (NEFT, RTGS, IMPS) } \\
\text { C_1_5 } \\
\text { Mobile banking (NEFT, RTGS, IMPS } \\
\text { through mobile app of your service } \\
\text { provider) } \\
\text { C_1_6 } \\
\text { Pre-paid cards (Gift cards, travel cards, } \\
\text { Sodexo, Bank pre-paid cards etc.) } \\
\text { C_1_7 } \\
\text { Mobile wallets (PayTM, PhonePe etc.) } \\
\text { C_1_8 } \\
\text { AEPS (Aadhar enabled payments system, } \\
\text { payment requires Aadhaar Card, finger- } \\
\text { print etc.) } \\
\text { C_1_9 } \\
\text { *99\#/ USSD (Unstructured Supplementary } \\
\text { Service data) }\end{array}$ & $\begin{array}{l}\text { 0. Not Aware } \\
\text { 1. Aware }\end{array}$ \\
\hline
\end{tabular}


Table 8 (continued)

\begin{tabular}{|c|c|c|c|}
\hline Question number & Question & Sub-question & Options \\
\hline $\begin{array}{l}\text { C_2 } \\
\text { (S23) }\end{array}$ & & $\begin{array}{l}\text { C_2_1 } \\
\text { Never share OTP/PIN/passwords of bank } \\
\text { accounts or cards with friends/family/ } \\
\text { unknown sources } \\
\text { C_2_2 } \\
\text { Share your bank account number when } \\
\text { RBI (Reserve Bank of India) calls/mails } \\
\text { you } \\
\text { C__2_3 } \\
\text { Never change your PIN/passwords of your } \\
\text { bank accounts/cards/wallets }\end{array}$ & $\begin{array}{l}\text { These options are coded as } \\
\text { C_2_1 } \\
\text { 1. Correct } \\
\text { (a) SAFE } \\
\text { 0. Not Correct } \\
\text { (b) NOT SAFE, (c) Do not know } \\
\text { (d) No response } \\
\text { C_2_2 } \\
\text { 1. Correct } \\
\text { (b) NOT SAFE } \\
\text { 0. Not correct } \\
\text { (a) SAFE } \\
\text { (c) Do not know } \\
\text { (d) No response } \\
\text { C_2_3 } \\
\text { 1. Correct } \\
\text { (b) NOT SAFE } \\
\text { 0. Not correct } \\
\text { (a) SAFE } \\
\text { (c) Do not know } \\
\text { (d) No response } \\
\text { C_2_4 } \\
\text { Total } \\
\text { score=CC_2_1 + C_2_2+C__2_3 }\end{array}$ \\
\hline $\begin{array}{l}\text { C_3 } \\
\text { (S27) }\end{array}$ & $\begin{array}{l}\text { Which of these do you save/ invest in? } \\
\text { What advantages do they give you? } \\
\text { Choose savings/ investment options that } \\
\text { you use and click on the checkboxes } \\
\text { accordingly }\end{array}$ & $\begin{array}{l}\text { C_3_1_1-C_3_1_5 } \\
\text { Bank savings account } \\
\text { C_3_2_1-C_3_2_5 } \\
\text { Bank fixed deposit } \\
\text { C_3_3_1-C_3_3_5 } \\
\text { Stocks/Equity } \\
\text { C_3_4_1-C_3_4_5 } \\
\text { Mutual funds } \\
\text { C_3_5_1-C_3_5_5 } \\
\text { Insurance } \\
\text { C_3_6_1-C_3_6_5 } \\
\text { Provident fund } \\
\text { C_3_7_1-C_3_7_5 } \\
\text { NSC (National savings certificate)/KVP } \\
\text { (Kisan Vikas Patra) } \\
\text { C_3_8_1-C_3_8_5 } \\
\text { Government bond } \\
\text { C_3_9_1-C_3_9_5 } \\
\text { Real estate } \\
\text { C_3_10_1-C_3_10_5 } \\
\text { Gold }\end{array}$ & 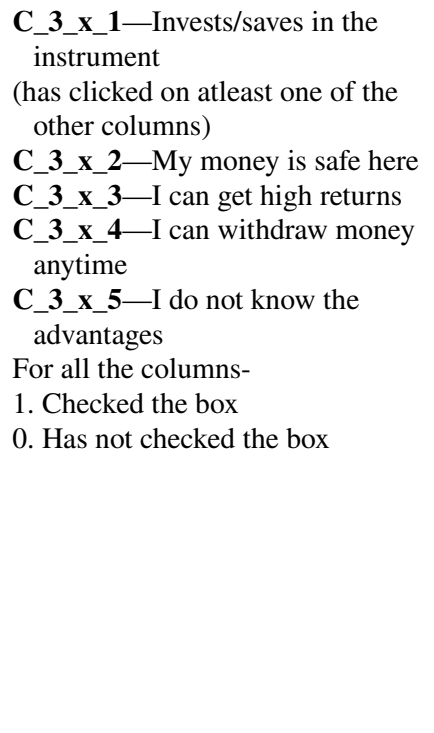 \\
\hline
\end{tabular}


Table 9 D. Preference and perception on cash and digital payment systems

\begin{tabular}{|c|c|c|c|}
\hline Question number & Question & Sub-question & Options \\
\hline $\begin{array}{l}\text { D_1 } \\
(\mathrm{S} 17)\end{array}$ & On a scale of 0 to 2 , rate $\mathrm{CASH}$ & $\begin{array}{l}\text { D_1_1 } \\
\text { Convenience } \\
\text { D_1_2 } \\
\text { Less Costly } \\
\text { D_1_3 } \\
\text { Privacy/Anonymity } \\
\text { D_1_4 } \\
\text { Safe/Secure }\end{array}$ & $\begin{array}{l}\text { 0. Bad } \\
\text { 1. Okay } \\
\text { 2. Good } \\
\text { 99. No response }\end{array}$ \\
\hline $\begin{array}{l}\text { D_2 } \\
(\mathrm{S} 18)\end{array}$ & On a scale of 0 to 2, rate DIGITAL PAYMENTS & $\begin{array}{l}\text { D_2_1 } \\
\text { Convenience } \\
\text { D_2_2 } \\
\text { Less Costly } \\
\text { D_2_3 } \\
\text { Privacy/Anonymity } \\
\text { D_2_4 } \\
\text { Safe/Secure }\end{array}$ & $\begin{array}{l}\text { 0. Bad } \\
\text { 1. Okay } \\
\text { 2. Good } \\
\text { 99. No response }\end{array}$ \\
\hline $\begin{array}{l}\text { D_3 } \\
(\mathrm{S} 19)\end{array}$ & $\begin{array}{l}\text { What are the main HURDLES in the adoption and usage of } \\
\text { digital payments for you? (Choose a maximum of 5) }\end{array}$ & $\begin{array}{l}\text { D_3_1 } \\
\text { Technological problems } \\
\text { Poor internet connectivity } \\
\text { lack of devices (proper phone/ } \\
\text { computer) } \\
\text { D_3_2 } \\
\text { Discomfort using technology } \\
\text { I am not comfortable using } \\
\text { mobile phone/computer } \\
\text { I get overwhelmed with the } \\
\text { number of apps and websites } \\
\text { providing the service } \\
\text { D_3_3 } \\
\text { transaction cost is high } \\
\text { D_3_4 } \\
\text { lack of trust in online payments } \\
\text { (unsafe, risky, declined transac- } \\
\text { tion) } \\
\text { D_3_5 } \\
\text { the KYC process is difficult to } \\
\text { get done } \\
\text { D_3_6 } \\
\text { language is a barrier } \\
\text { D_3_7 } \\
\text { It is not accepted everywhere } \\
\text { D_3_8 } \\
\text { I do not relate to any of the above } \\
\text { statements } \\
\text { Other } \\
\text { No response } \\
\text { D_3_9 } \\
\text { I have no problems }\end{array}$ & \\
\hline $\begin{array}{l}\text { D_4 } \\
(\mathrm{S} 16)\end{array}$ & Choose your best response to the following statements & $\begin{array}{l}\text { D_4_1 } \\
\text { It is safer to deposit money in a } \\
\text { bank than keeping it at home } \\
\text { D_4_2 } \\
\text { I have confidence in my bank(s) } \\
\text { D_4_3 } \\
\text { I trust service providers of my } \\
\text { e-wallet/mobile app (other than } \\
\text { banks) } \\
\text { D_4_4 } \\
\text { I have confidence in the Reserve } \\
\text { Bank of India }\end{array}$ & $\begin{array}{l}\text { 0. Strongly } \\
\text { agree } \\
\text { 1. Agree } \\
\text { 2. Neither agree } \\
\text { nor disagree } \\
\text { 3. Disagree } \\
\text { 4. Strongly } \\
\text { disagree } \\
\text { 99. No response }\end{array}$ \\
\hline
\end{tabular}


Table 10 E. Behavioural aspects/habits of spending

\begin{tabular}{|c|c|c|c|}
\hline Question number & Questions & Sub-questions & Options \\
\hline $\begin{array}{l}\text { E_1 } \\
(\mathrm{S} 10)\end{array}$ & $\begin{array}{l}\text { How do you receive your SALARY/ } \\
\text { MONEY for your expenses? }\end{array}$ & & $\begin{array}{l}\text { Directly in my account/e-wallet } \\
\text { Through CHEQUE } \\
\text { In CASH } \\
\text { Both Cash and Cheque } \\
\text { Cash/Cheque and also in my account/e- } \\
\text { wallet } \\
\text { 99. No response }\end{array}$ \\
\hline $\begin{array}{l}\text { E_2 } \\
(\mathrm{S} 8)\end{array}$ & Have you used the following? & $\begin{array}{l}\text { E_2_4 } \\
\text { Internet banking (NEFT, RTGS, IMPS) } \\
\text { E_2_5 } \\
\text { Mobile banking (NEFT, RTGS, IMPS } \\
\text { through mobile app of your service } \\
\text { provider) } \\
\text { E_2_6 } \\
\text { Pre-paid cards (Gift cards, travel cards, } \\
\text { Sodexo, Bank pre-paid cards etc.) } \\
\text { E_2_7 } \\
\text { Mobile wallets (PayTM, PhonePe etc.) } \\
\text { E_2_8 } \\
\text { AEPS (Aadhar enabled payments sys- } \\
\text { tem, payment requires Aadhaar Card, } \\
\text { fingerprint etc.) } \\
\text { E_2_9 } \\
\text { USSD (Unstructured Supplementary } \\
\text { Service data)/*99\# }\end{array}$ & $\begin{array}{l}\text { More than once (Regularly/monthly etc.) } \\
\text { Only once } \\
\text { Has not used }\end{array}$ \\
\hline $\begin{array}{l}\text { E_3 } \\
(\mathrm{S} 11)\end{array}$ & $\begin{array}{l}\text { What do you use to PAY for the fol- } \\
\text { lowing? }\end{array}$ & $\begin{array}{l}\text { E_3_1 } \\
\text { Grocery } \\
\text { E_3_2 } \\
\text { Other consumables (clothes, footwear, } \\
\text { stationery) } \\
\text { E_3_3 } \\
\text { Online Shopping, Ordering food online } \\
\text { E_3_4 } \\
\text { Utilities (Electricity, gas etc.) } \\
\text { E_3_5 } \\
\text { Hotels/Restaurants } \\
\text { E_3_6 } \\
\text { Durables(Microwave, TV etc.) } \\
\text { E_3_7 } \\
\text { Petrol pump/Taxi } \\
\text { E_3_8 } \\
\text { Financial Transactions (banks, insur- } \\
\text { ance, mutual funds, stocks) } \\
\text { E_3_9 } \\
\text { Gold }\end{array}$ & $\begin{array}{l}\text { 0. Cash/Cash on delivery } \\
\text { 1. Digital } \\
\text { 2. Payments } \\
\text { 3. Both } \\
\text { 99. No response }\end{array}$ \\
\hline $\begin{array}{l}\text { E_4 } \\
(\mathrm{S} 12)\end{array}$ & $\begin{array}{l}\text { In the last } 1-3 \text { months, has your usage/ } \\
\text { DEPENDENCE on DIGITAL PAY- } \\
\text { MENTS changed? }\end{array}$ & & $\begin{array}{l}\text { 0. I have completely switched to digital } \\
\text { payments } \\
\text { 1. It has increased } \\
\text { 2. It has decreased } \\
\text { 3. It has not changed } \\
\text { 99. No response }\end{array}$ \\
\hline $\begin{array}{l}\text { E_5 } \\
\text { (S13) }\end{array}$ & $\begin{array}{l}\text { If your usage/dependence has } \\
\text { INCREASED, would it REMAIN } \\
\text { THE SAME after COVID-19 recedes? }\end{array}$ & & $\begin{array}{l}\text { 0. Does not apply to me } \\
\text { 1. Yes, the increase is permanent } \\
\text { 2. No, I will go back to using cash more } \\
\text { 3. Do not know } \\
\text { 99. No response }\end{array}$ \\
\hline
\end{tabular}


Table 10 (continued)

Question number Questions Sub-questions

Options

E_6 If your usage/ dependence on digital

(S14) payments has increased then, what is the MAIN REASON?

E_7
How is your online buying experience of goods and services on the following aspects?
E_7_1

Quality of Goods

E_7_2

Refund of Goods

E_7_3

Customer service
0 . Does not apply to me

1. I cannot access cash through ATMs

2. I fear contracting the virus through bank notes

3. I feel digital payments are more convenient

4. Others

99. No response

0 . Unsatisfactory

1. Satisfactory

99. No response

Table 11 F. Experience related to fraud

\begin{tabular}{|c|c|c|}
\hline Question number & Question & Options \\
\hline $\begin{array}{l}\text { F_1 } \\
(\mathrm{S} 20)\end{array}$ & $\begin{array}{l}\text { What is your experience with Digital payments FRAUD } \\
\text { (On-call fraudsters, phishing etc.)? }\end{array}$ & $\begin{array}{l}\text { 0. I have been a VICTIM to digital payment frauds } \\
\text { 1. I have RECEIVED such calls/mails/texts but carefully } \\
\text { AVOIDED it } \\
\text { 2. I HAVE NOT received such calls/mail/texts but know } \\
\text { someone PERSONALLY who has been a victim } \\
\text { 3. I HAVE NOT received such calls/mail/texts and DO NOT } \\
\text { know anyone PERSONALLY who has been a victim } \\
\text { 99. No response }\end{array}$ \\
\hline $\begin{array}{l}\text { F_2 } \\
(\mathrm{S} 21)\end{array}$ & $\begin{array}{l}\text { If you have been a victim or carefully avoided the fraud, then } \\
\text { was the case reported to the concerned authority? }\end{array}$ & $\begin{array}{l}0 . \text { Does not apply to me } \\
\text { 1. No, I did not report it } \\
\text { 2. Yes, I reported it } \\
\text { 99. No response }\end{array}$ \\
\hline $\begin{array}{l}\text { F_3 } \\
(\mathrm{S} 22)\end{array}$ & $\begin{array}{l}\text { If you have AVOIDED or been a VICTIM to such a fraud, } \\
\text { then have you REDUCED your digital payments usage? }\end{array}$ & $\begin{array}{l}\text { 0. It does not apply to me } \\
\text { 1. YES, I have completely switched to cash/cheque } \\
\text { 2. YES, I have reduced the use of digital payments } \\
\text { 3. NO, It has not affected the use of digital payments but I am } \\
\text { more careful now } \\
\text { 99. No response }\end{array}$ \\
\hline
\end{tabular}


Table 12 G. Feedback on awareness campaigns

\begin{tabular}{|c|c|c|c|}
\hline Question number & Question & Sub-question & Options \\
\hline $\begin{array}{l}\text { G_1 } \\
(\mathrm{S} 24)\end{array}$ & $\begin{array}{l}\text { Most of my information regarding digital } \\
\text { payments comes from }\end{array}$ & $\begin{array}{l}\text { G_1_1 } \\
\text { News (Newspaper, TV, Internet } \\
\text { G_1_2 } \\
\text { Ads on Internet or TV } \\
\text { G_1_3 } \\
\text { YouTube, blogs } \\
\text { G_1_4 } \\
\text { Bank employees } \\
\text { Customer care } \\
\text { G_1_5 } \\
\text { RBI's/ NCPI's website } \\
\text { Service provider's website } \\
\text { G_1_6 } \\
\text { Friends/ family } \\
\text { G_1_7 } \\
\text { Others } \\
\text { None } \\
\text { No response }\end{array}$ & $\begin{array}{l}\text { 0. Does not come from this source } \\
\text { 1. Comes from this source }\end{array}$ \\
\hline $\begin{array}{l}\text { G_2 } \\
(\mathrm{S} 25)\end{array}$ & $\begin{array}{l}\text { Can you REMEMBER/RECALL these } \\
\text { commercial/ads? You may have watched/ } \\
\text { read/listened to these }\end{array}$ & $\begin{array}{l}\text { G_2_1 } \\
\text { RBI SAYS/ RBI KEHTA HAI. RBI } \\
\text { (Reserve bank of India) has come up } \\
\text { with a series of commercials/ads under } \\
\text { the campaign "RBI Says" or "RBI Kehta } \\
\text { hai" to promote awareness on 'Safe Digi- } \\
\text { tal Banking,, 'Banking Ombudsman', } \\
\text { 'Basic Savings Bank Deposit Account', } \\
\text { 'Risk v/s return', etc } \\
\text { G_2_2 } \\
\text { UPI CHALEGA and ONE LIFE. ONE } \\
\text { RUPAY. NPCI 's (National Payments } \\
\text { Corporation of India) series of com- } \\
\text { mercial/ads under the campaign "UPI } \\
\text { Chalega" and "One Life. One Rupay" } \\
\text { G_2_3 } \\
\text { INDIA PAY SAFE. Reserve Bank of } \\
\text { India (RBI) Governor Shaktikanta Das' } \\
\text { address to the nation urging citizens to } \\
\text { use digital payment system under the } \\
\text { campaign "India Pay Safe" }\end{array}$ & $\begin{array}{l}0 . \text { Does not recall } \\
1 . \text { Recalls }\end{array}$ \\
\hline $\begin{array}{l}\text { G_3 } \\
(\mathrm{S} 26)\end{array}$ & $\begin{array}{l}\text { If you REMEMBER some/ all of the ads, } \\
\text { then do you think the ads were helpful? } \\
\text { If so, why? }\end{array}$ & $\begin{array}{l}\text { G_3_1 } \\
\text { Positive feedback } \\
\text { YES, I found the ads to be informative } \\
\text { YES, I have gained more trust in the bank- } \\
\text { ing system for proper grievance redressal } \\
\text { if needed } \\
\text { G_3_2 } \\
\text { NO, the ads can be more informative } \\
\text { G_3_3 } \\
\text { NO, I did not like the ads } \mathbf{G} \_\mathbf{3} \_\mathbf{4} \\
\text { Other reasons } \\
\text { I do not recall these ads } \\
\text { No response } \\
\text { G_3_4 } \\
\text { Other reasons } \\
\text { I do not recall these ads } \\
\text { No response }\end{array}$ & $\begin{array}{l}0 . \text { Has not chosen this option } \\
1 \text {. Has chosen this option }\end{array}$ \\
\hline $\begin{array}{l}\text { G_4 } \\
(\mathrm{S} 28)\end{array}$ & $\begin{array}{l}\text { PLEASE, give brief feedback on digital } \\
\text { payments. [The feedback can be in sen- } \\
\text { tences, phrases or a set of words] }\end{array}$ & & 99. No response \\
\hline
\end{tabular}




\section{Appendix 2}

See Appendix Fig. 3.

Fig. 3 Data summary
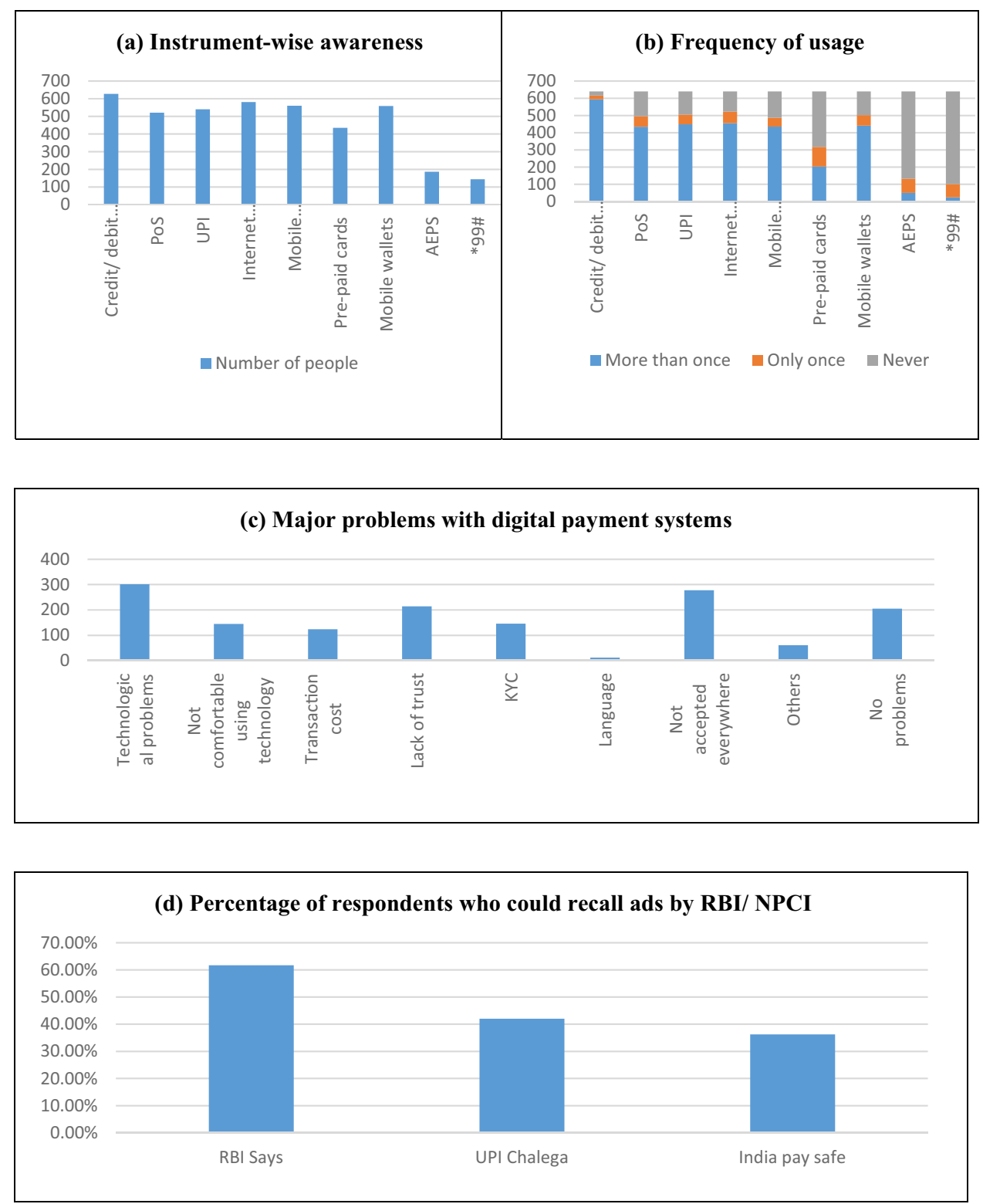
Fig. 3 (continued)

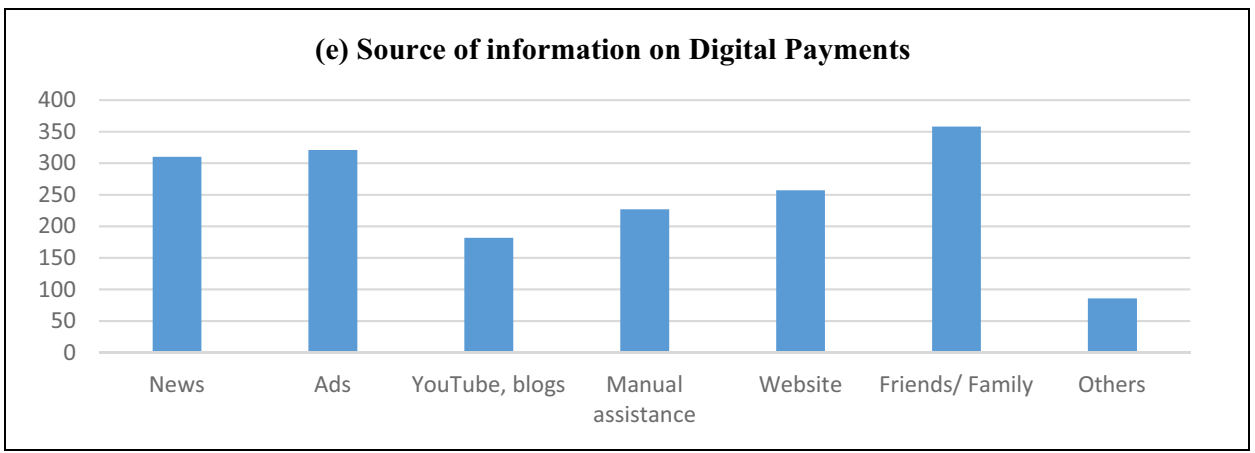

\begin{tabular}{|c|c|c|c|c|}
\hline \multicolumn{5}{|c|}{ (f) Online Fraud Experience - Summary of Responses } \\
\hline & Reported & $\begin{array}{l}\text { Not } \\
\text { reported }\end{array}$ & $\begin{array}{l}\text { Didn't } \\
\text { reveal }\end{array}$ & Total \\
\hline Victim of online fraud & 36 & 11 & 5 & 52 \\
\hline Received such a call/ text but avoided loss & 58 & 170 & 131 & 359 \\
\hline Know someone who has experienced it & & & & 121 \\
\hline No experience & & & & 98 \\
\hline Vertical sum & 94 & 181 & 136 & 630 \\
\hline
\end{tabular}

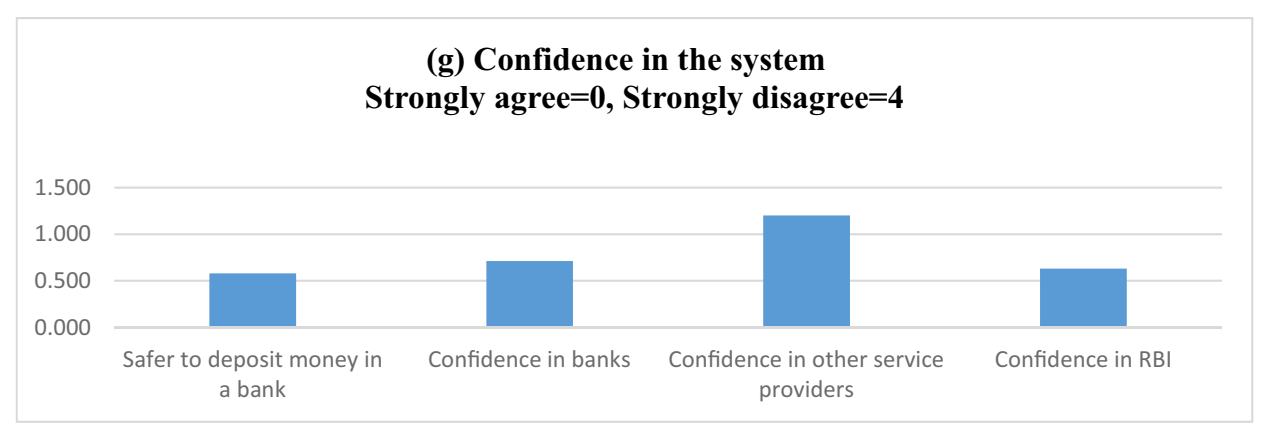

(f) Perception of cash and digital payment

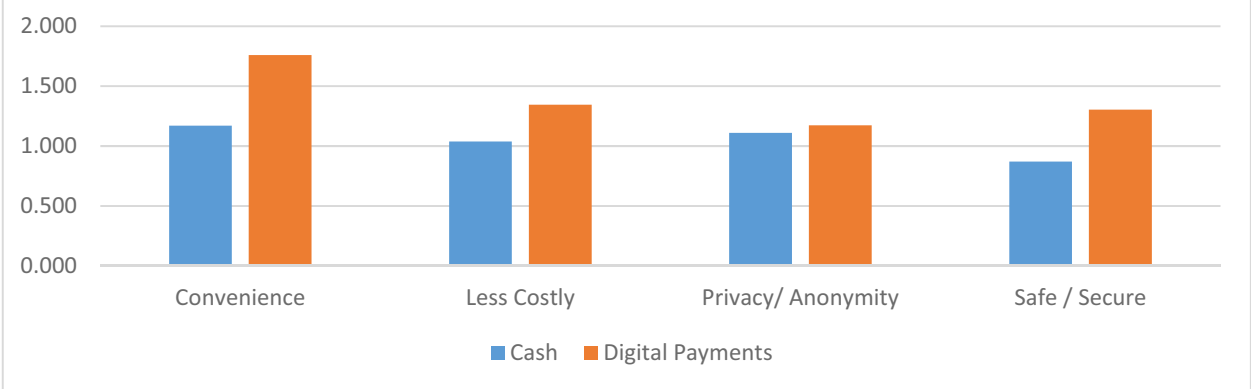




\section{Appendix 3}

See Appendix Table 13.

Table 13 Regression Table for Baseline Model

\begin{tabular}{|c|c|c|c|c|c|}
\hline & \multicolumn{5}{|l|}{ Baseline model } \\
\hline & Grocery & Utilities & Durables & Online shopping & Gold \\
\hline Intercept (DP) & $-17.214(1,785.172)$ & $-0.399(0.919)$ & $-0.312(1.027)$ & $-0.511(1.187)$ & $-2.089^{*}(1.07)$ \\
\hline Intercept (Both) & $0.566(0.691)$ & $0.557(0.891)$ & $1.495 *(0.903)$ & $1.490(1.018)$ & $-0.019(0.817)$ \\
\hline Female & 0 & 0 & 0 & 0 & 0 \\
\hline Male (DP) & $1.073 * * *(0.381)$ & $1.043 * * *(0.322)$ & $-0.004(0.352)$ & $0.824 *(0.430)$ & $0.238(0.305)$ \\
\hline Male (Both) & $0.535 * *(0.252)$ & $0.916^{* * * *}(0.348)$ & $0.093(0.350)$ & $0.242(0.421)$ & $0.585^{* *}(0.291)$ \\
\hline Below 25 & 0 & 0 & 0 & 0 & 0 \\
\hline 26-45 (DP) & $0.837(0.513)$ & $-0.359(0.486)$ & $0.632(0.521)$ & $0.447(0.646)$ & $0.492(0.469)$ \\
\hline 26-45 (Both) & $0.149(0.387)$ & $-0.582(0.521)$ & $-0.142(0.531)$ & $0.562(0.651)$ & $-0.067(0.442)$ \\
\hline Above 46 (DP) & $0.186(0.641)$ & $-0.484(0.640)$ & $0.963(0.779)$ & $-1.354 * *(0.690)$ & $-0.253(0.567)$ \\
\hline Above 46 (Both) & $-0.088(0.504)$ & $-0.360(0.685)$ & $0.715(0.786)$ & $-1.312 *(0.703)$ & $-0.305(0.543)$ \\
\hline Completed 12th & 0 & 0 & 0 & 0 & 0 \\
\hline Bachelors (DP) & $15.921(1,785.172)$ & $1.216^{* *}(0.558)$ & $0.679(0.682)$ & $1.266(0.819)$ & $0.500(0.704)$ \\
\hline Bachelors (Both) & $0.914 * *(0.451)$ & $1.181 * *(0.578)$ & $0.224(0.568)$ & $0.709(0.702)$ & $1.066^{*}(0.619)$ \\
\hline Masters (DP) & $\begin{array}{l}16.607 \\
(1,785.172)\end{array}$ & $1.503 * *(0.607)$ & $0.990(0.721)$ & $0.526(0.837)$ & $0.315(0.726)$ \\
\hline Masters (Both) & $1.241 * *(0.489)$ & $1.546 * *(0.635)$ & $0.218(0.622)$ & $-0.489(0.728)$ & $0.916(0.647)$ \\
\hline Below 2.5 lakhs & 0 & 0 & 0 & 0 & 0 \\
\hline 2.5-5 lakhs (DP) & $0.449(0.921)$ & $-0.465(0.736)$ & $0.122(0.698)$ & $1.555^{*}(0.848)$ & $0.812(0.878)$ \\
\hline 2.5-5 lakhs (Both) & $-0.331(0.486)$ & $-1.098(0.705)$ & $-0.252(0.618)$ & $0.434(0.728)$ & $-0.355(0.561)$ \\
\hline 5-10 lakhs (DP) & $-0.343(0.899)$ & $-0.117(0.710)$ & $0.563(0.679)$ & $1.521 *(0.824)$ & $1.425^{*}(0.852)$ \\
\hline 5-10 lakhs (Both) & $-0.191(0.461)$ & $-1.320 *(0.687)$ & $0.011(0.605)$ & $0.577(0.707)$ & $-0.234(0.546)$ \\
\hline 10-25 lakhs (DP) & $1.034(0.891)$ & $0.368(0.727)$ & $1.003(0.704)$ & $2.021 * *(0.842)$ & $2.229 * * *(0.855)$ \\
\hline 10-25 lakhs (both) & $0.434(0.481)$ & $-1.233^{*}(0.714)$ & $0.066(0.642)$ & $0.529(0.733)$ & $-0.203(0.564)$ \\
\hline Above 25 lakhs (DP) & $1.426(1.000)$ & $1.054(0.911)$ & $1.065(0.842)$ & $3.016 * * *(1.103)$ & $2.351 * *(0.948)$ \\
\hline Above 25 lakhs (both) & $0.986(0.603)$ & $-0.148(0.905)$ & $-0.010(0.804)$ & $1.564(1.025)$ & $0.447(0.696)$ \\
\hline occupation 1:1 (DP) & $-2.155 * * *(0.669)$ & $-1.077 *(0.609)$ & $-1.398 * *(0.644)$ & $-1.880 * * *(0.675)$ & $-0.177(0.567)$ \\
\hline occupation 1:2 (Both) & $-1.425 * * *(0.462)$ & $-0.439(0.623)$ & $-1.148 *(0.650)$ & $-0.517(0.651)$ & $-0.991 *(0.579)$ \\
\hline Occupation 2:1 & $0.092(0.786)$ & $-0.654(0.730)$ & $15.237(2,130.428)$ & $-0.567(0.716)$ & $1.497 *(0.882)$ \\
\hline Occupation 2:2 & $-0.071(0.691)$ & $-0.651(0.802)$ & $14.740(2,130.428)$ & $0.185(0.748)$ & $0.477(0.893)$ \\
\hline Occupation $3: 1$ & $-1.997 * * *(0.596)$ & $-0.711(0.483)$ & $-1.189 * *(0.524)$ & $-1.156^{*}(0.634)$ & $-0.373(0.473)(0.473)$ \\
\hline Occupation $3: 2$ & $-0.984 * * *(0.374)$ & $-0.368(0.512)$ & $-0.905^{*}(0.522)$ & $0.149(0.628)$ & $-0.749 *(0.433)$ \\
\hline Occupation 4:1 & $-2.490 * *(1.111)$ & $-0.225(0.692)$ & $-2.160 * * *(0.633)$ & $-0.948(0.788)$ & $0.917(0.703)$ \\
\hline Occupation $4: 2$ & $-1.171 * *(0.510)$ & $-0.801(0.817)$ & $-2.562 * * *(0.715)$ & $-0.516(0.791)$ & $-0.572(0.753)$ \\
\hline Location x (DP) & $0.101(0.430)$ & $1.283^{* * * *}(0.374)$ & $1.261 * * *(0.411)$ & $0.305(0.520)$ & $0.529(0.360)$ \\
\hline Location x (Both) & $-0.625 * *(0.311)$ & $0.102(0.399)$ & $0.058(0.401)$ & $-0.349(0.512)$ & $-0.233(0.332)$ \\
\hline Location y (DP) & $-0.129(0.489)$ & $-0.073(0.367)$ & $0.600(0.438)$ & $-0.184(0.539)$ & $0.127(0.411)$ \\
\hline Location y (Both) & $-0.480(0.337)$ & $-0.303(0.382)$ & $0.072(0.418)$ & $-0.636(0.526)$ & $0.142(0.368)$ \\
\hline Observations & 553 & 549 & 516 & 548 & 464 \\
\hline $\mathrm{R} 2$ & 0.146 & 0.106 & 0.130 & 0.134 & 0.082 \\
\hline Log Likelihood 4 & -457.22 & -443.032 & -421.363 & -425.130 & -452.345 \\
\hline LR Test (df=32) & $156.388 * * *$ & $104.989 * * *$ & $126.056 * * *$ & $131.533 * * *$ & $80.589 * * *$ \\
\hline
\end{tabular}

$* p<0.1 ; * * p<0.05 ; * * * p<0.01$ 


\section{References}

1. Arango-Arango CA, Bouhdaoui Y, Bounie D, Eschelbach M, Hernandez L (2018) Cash remains top-of-wallet! International evidence from payment diaries. Econ Model 69:38-48

2. Bagnall J, Bounie D, Huynh KP, Kosse A, Schmidt T, Schuh SD, Stix H (2014) Consumer cash usage: a cross-country comparison with payment diary survey data. Int J Cent Bank (46)

3. Cagan P (1958) The Demand for Currency Relative to the Total Money Supply. J Political Econ 66(4):302-328

4. Chen A, Zeltmann S, Griffin K, Ota M, Ozeki R (2020) Demographic background, perceptions, and e-payment usage among young Japanese. Glob J Bus Discip 4(1):4

5. Ernst and Young (EY) (2019) EY Global FinTech Adoption Index 2019.

6. European Central Bank (2018) Econ Bull (6)

7. Galiani S, Gertler P, Ahumada CN (2020) Trust and Saving in Financial Institutions (No. w26809). Natl Bur Econ Res

8. Garcia-Swartz DD, Hahn RW, Layne-Farrar A (2006) The move toward a cashless society: a closer look at payment instrument economics. Rev Netw Econ 5(2)

9. Jonker N (2007) Payment instruments as perceived by consumersresults from a household survey. De Economist 155(3):271-303

10. Kahn CM, McAndrews J, Roberds W (2005) Money is privacy. Int Econ Rev 46(2):377-399

11. Kosse A (2013) Do newspaper articles on card fraud affect debit card usage? J Bank Finance 37(12):5382-5391

12. Lai PC (2017) Security as an extension to TAM model: Consumers' intention to use a single platform E-Payment. Asia-Pac J Manage Res Innov 13(3-4):110-119
13. Maqableh M (2015) Perceived trust and payment methods: an empirical study of MarkaVIP company. Int J Commun Netw Syst Sci 8(11):409

14. Mazzotta B, Chakravorti, B, Bijapurkar R, Shukla R, Ramesha K, Bapat D, Roy D (2019). The Cost of Cash in India. The Institute for Business in the Global Context

15. Nilekani N (2019) Report of the High Level Committee on Deepening of Digital Payments, Reserve Bank of India

16. Png I, Tan C (2019) Privacy, Trust in Banks and Use of Cash, Macroeconomic Review Volume XIX Issue 1 April 2020, Monetary Authority of Singapore (ISSN 0219-8908)

17. Prelec D, Loewenstein G (1998) The red and the black: Mental accounting of savings and debt. Market Sci 17(1):4-28

18. Ozturk AB (2016) Customer acceptance of cashless payment systems in the hospitality industry. International Journal of Contemporary Hospitality Management

19. Rick SI (2018) Tightwads and spendthrifts: An interdisciplinary review. Financ Plan Rev 1(1-2):e1010. https://doi.org/10.1002/ cfp2.1010

20. Rogoff K (2015) Costs and benefits to phasing out paper currency. NBER Macroecon Annu 29(1):445-456

21. Tanzi V (1983) The Underground Economy in the United States: Estimates and Implications. Staff Papers-International Monetary Fund 30(2):283-305

22. Vinitha K, Vasantha S (2017) Influence of demographic variables on usage of e-payment system. Int J Mech Eng Technol (IJMET) $8: 265-276$

23. VISA (2016) Accelerating the growth of digital payments in India: a five-year outlook 